\title{
Beberapa Kebijaksanaan dan Hasil yang Dicapai dalam Industrialisasi Indonesia
}

\author{
Oleh : Marjono
}

MARJONO, lahir dl Jakarta 1 Jull 1940. Program S-1 diselesalkan dl ITB Jurusan Tambang pada tahun 1965. Sejak tahun 1989'sampal saat Inl menjabat sebagal Ka. Kanwll. Departemen Perindustrian Prop. DIY, pengalaman kerja yang lain, pada tahun 1965 dl Departemen Perindustrian, sedangkan pada tahun 1977 - 1983 pernah menjabat sebagal Ka. Kanwil Departemen Perindustrlan dI Ball dan dl Kallmantan Selatan pada tahun 1983 - 1989.

Memasuki tahun-tahun akhir dari pembangunan jangka panjang 25 tahun pertama ini, perkembangan industri nasional bergerak semakin cepat, dan kian meluas keterkaitannya dengan sektor ekonomi lainnya yaitu dengan sektor pertanian, kehutanan, pertambangan migas/non migas serta aspek kehidupan nasional baik ekonomi, politik, sosial budaya, maupun hankam.
Apabila kita simak tampak jelas bahwa industri nasional pada tahun 1991. sudah mampu memenuhi amanat GBHN, yaitu :

1. Terwujudnya-struktur ekonomi yang seimbang yaitu industri yang maju didukung oleh pertanian yang tangguh. Hal ini tercermin pada laju pertumbuhan industri dan sumbangannya pada PDB.

Tabel 1 : Pertumbuhan Industri dan Sumbangannya pada PDB

\begin{tabular}{|c|c|c|c|c|c|}
\hline \multirow{2}{*}{ TAHUN } & \multicolumn{3}{|c|}{ LAJU PERTUMBUHAN } & \multicolumn{2}{c|}{ SUMBANGAN PADA:PDB } \\
\cline { 2 - 6 } & Eronomi & Pertanian & Industri & Pertanian & Industri \\
\hline \multirow{2}{*}{1989} & $7,5 \%$ & $3,12 \%$ & $11,57 \%$ & $20,58 \%$ & $18,48 \%$ \\
1990 & $7,3 \%$ & $251 \%$ & $12,8 \%$ & $21,52 \%$ & $20,32 \%$ \\
1991 & $6,57 \%$ & $1,03 \%$ & $11,03 \%$ & $19,62 \%$ & $22,22 \%$ \\
\hline
\end{tabular}


Perkembangan tersebut di atas menunjukkan pada tahun 1991 sudah terwujud struktur ekonomi yang seimbang, dua tahun lebih cepat dari rencana. Menurut rencana keseimbangan struktur ekonomi baru tercapai pada akhir Pelita V, tahun 1993/1994.

2. Industri menjadi penggerak utama pembangunan.

Dengan pemberian arah yang jelas utamanya pengembangan industri yang berorientasi ekspor, kemampuan dunia usaha yang kian meningkat dengan dukungan iklim usaha yang kondusif serta penyediaan sarana dan prasarana yang memadai maka ekspor non migas mampu menjadi penggerak utamanya pembangunan. Dalam ekspor non migas peranan ekspor hasi industri semakin dominan, selain menjadi penghasil devisa yang besar juga telah menggerakkan ekoriomi masyarakat. Pada tahun "1991 peranan ekspor hasil industri semakin dominan, rata-rata mencapai lebih $84 \%$ dari ekspor non migas dan merupakan lebih dari $53 \%$ total ekspor Indonesia.

3. Industri siap tinggal landas.

Pembangunan industri telah berkembang meningkat. Menurut UNIDO, bagi negara berkembang yang melakukan industrialisasi, apabila peranan industri pada PDB melampaui $15 \%$ maka pertumbuhannya akan bergerak cepat. Kemudian apabila sumbangan pada PDB sudah lebih dari $20 \%$, negara itu sudah memasuki era industri. Dengan sumbangan pada PDB 22,22\% pada tahun 1991, maka industri nasional pada posisi siap tinggal landas. Keseluruhan kelompok Industri Kimia Dasar, Kelompok Industri Mesin, Logam Dasar dan Elektronika, Kelompok Aneka Industri sudah dalam keadaan siap tinggal landas, sedangkan untuk kelompok Industri Kecil yang siap tinggal landas adalah sistem pembinaannya yang memungkinkan berkembangnya industri kecil dan kerajinan menjadi mandiri. Dengan mengamati upaya serta hasilhasil yang telah dicapai, maka industri nasional mampu siap tinggal landas dalam Pelita VI yang akan datang sebagai awal langkah memasuki Pembangunan Jangka Panjang 25 Tahun Kedua menuju kemandirian bangsa.

\section{Ekspor Hasil Industri}

Ekspor hasil industri terus meningkat dari tahun ke tahun. Pada tahun 1991 mencapai US\$ 15,3 milyar, meningkat $27 \%$ dibanding tahun 1990 dan merupakan $84 \%$ ekspor non migas, serta 53\% dari total ekspor Indonesia. Keberhasilan ekspor hasil industri yang digerakkan secara luas (broad spectrum) sejak awal Pelita IV telah berhasil merubah strktur ekspor Indonesia dari ekspor migas keekspor non migas. Perubahan struktur tersebut telah memberikan landasan yang semakin kokoh perekonomian Indonesia yang tercermin pada:

(1) Diversifikasi produk dan pasar. Dengan pola spektrum yang luas (broad spectrum), jenis produk/komoditi hasil industri semakin banyak dengan jangkauan pasar yang terus meluas. Lebih-lebih setelah berhasil didorong pengembangan industri yang berdaya saing kuat, maka produk andalan ekspor hasil industri terus bertambah dan berhasil memasuki pasaran global.

(2) Peranan ekspor hasil industri baik terhadap. ekspor non migas maupun total ekspor semakin dominan seperti data ini: 
Tabel 2 : Ekspor Hasil Industri

(dalam US\$ juta )

\begin{tabular}{|c|c|c|c|c|c|c|}
\hline TAHUN & $\begin{array}{l}\text { TOTAL } \\
\text { EKSPOR }\end{array}$ & MIGAS & $\begin{array}{c}\text { NON } \\
\text { MIGAS }\end{array}$ & $\begin{array}{l}\text { HASIL } \\
\text { INDUSTRI }\end{array}$ & $\begin{array}{c}\text { \%PERAN HSL } \\
\text { THP NON } \\
\text { MIGAS }\end{array}$ & $\begin{array}{l}\text { \%PERAN HSL } \\
\text { IND THD } \\
\text { TOTAL }\end{array}$ \\
\hline \begin{tabular}{|l|}
1984 \\
1986 \\
1988 \\
1990 \\
1991
\end{tabular} & $\begin{array}{l}21.887,8 \\
14.805,0 \\
19.218,5 \\
25.675,2 \\
29.141,9\end{array}$ & $\begin{array}{r}10.018,1 \\
8.276,6 \\
7.681,6 \\
11.071,2 \\
10.894,9\end{array}$ & $\begin{array}{r}5.869,7 \\
6.528,4 \\
11.536,9 \\
14.604,1 \\
18.247,0\end{array}$ & $\begin{array}{r}4.229,0 \\
4.570,9 \\
9.387,9 \\
12.109,3 \\
15.386,0\end{array}$ & $\begin{array}{l}72,05 \% \\
70,15 \% \\
81,97 \% \\
82,92 \% \\
84,32 \%\end{array}$ & $\begin{array}{l}19,32 \% \\
30,93 \% \\
48,85 \% \\
47,16 \% \\
52,80 \%\end{array}$ \\
\hline
\end{tabular}

(3) Ekspor hasil industri telah mampu membiayai keperluan impor bahan baku/penolong sendiri bahkan sudah surplus. Prestasi ini dapat dijelaskan pada posisi ekspor tahun 1991.

a) Ekspor Hasil Industri tahun 1991 US\$ 15,386 milyar (naik $27,06 \%$ )

(1) Industri Primer : US $\$ 2,250$ milyar (naik 10,69\%)

(2) Industri Pengolahan (Manufaktur) : US\$ 13.127 milyar (naik 30,25\%)

b) Impor Bahan Baku/Penolong Sektor Industri Tahun 1991 : US\$ 9,377 milyar (naik 10,69\%)

Catatan :

Sebagian besar diimpor untuk industri pengolahan. Dengan demikian dapat disampaikan bahwa peningkatan ekspor hasil industri pengolahan masih di atas impor bahan bakulpenolong dengan surplus US\$ 6,61\% milyar.

c) Neraca ekspor hasil industri dan impor bahan baku industri tahun 1991, surplus US\$ 6,01 milyar. Pada tahun 1991 sektor industri secara keseluruhan berkembang dengan mantap; sebagian bahan baku dan penolong belum diproduksi di dalam negeri, maka realisasi impornya pada tahun 1991 juga meningkat, yaitu sebesar US\$ 9,377 milyar atau naik 10,69\% dibanding impor tahun 1990 sebesar US\$ 8,472 milyar. Perbandingan impor dan ekspor membaik dari 7 : 10 pada 1990 menjadi $6,1: 10$ pada tahun 1991 .

Demikian juga nilai impor sebesar US $\$ 15,386$ milyar dengan surplus US\$ 6,01 milyar.

\section{Masalah-masalah yang dihadapi.}

Dalam upaya peningkatan pengembangan industri nasional dalam tahun 1991 dan tahun-tahun mendatang, pengembangan industri masih menghadapi berbagai masalah baik masalah di dalam negeri maupun masalah-masalah dari luar negeri. Masalahmasalah tersebut yang pokok adalah :

1) Dari dalam negeri

a) Pertumbuhan industri yang semakin cepat masih harus diiringi dengan pemerataan pembangunan industri yang meluas.

1 Perkembangan industri dasar dan aneka industri bergerak cepat belum dapat diikuti secara serempak dengan perkembangan industri kecil yang mempunyai missi pemerataan. Perkembangan pembangunan industri yang masih belum seimbangan ini dapat menimbulkan kesenjangan. 
2 Pembangunan industri juga belum merata di seluruh wilayah Indonesia. Walaupun disadari bahwa pembangunan industri itu harus sesuai dengan potensi daerah masing-masing, namun masih banyak daerah di luar pulau Jawa yang potensial seperti IBT belum berkembang industrinya. Di daerah-daerah luar pulau Jawa yang potensial itu pembangunan industri harus ditingkatkan.

3 Kurang tersedianya para wiraswasta dan tenaga profesi yaitu para manajer, tenaga ahli, tenaga terdidik, tenaga terampil dan sebagainya dalam jumlah dan kualitas yang memadai, juga dalam penyebarannya di seluruh wilayah Indonesia.

4 Sarana dan prasarana yang masih kurang yaitu :

- listrik

- pelabuhain

- jalan

- telekomunikasi

- pengetatan kredit bank, dan lain-lain

5 Pencemaran lingkungan

Dalam pelaksanaan pembangunan dewasa ini mulai timbul masalah pencemaran yang mungkin dapat disebabkan oleh industri. Oleh karena itu dalam rangka mewujudkan pelaksanaan pembangunan industri berwawasan lingkungan dan berlanjutan, perlu diambil langkah preventif dan curatif antara lain berupa penindakan langsung bagi industri yang benar-benar mencemarkan lingkungan.

2) Dari luar negeri

Keadaan dunia masih penuh gejolak dan ketidakpastian. Perkembangan lingkungan strategis baik pada tingkat regional maupun internasional, mempunyai dampai negatif terhadap perkembangan industri nasional.

a) sikap proteksionisme baik melalui tarif maupun non tarif.

b) Resistensi negara-negara maju terhadap ekspor barang-barang industri negara-negara berkembang.

c) Praktek oligopoli dan kartel perusahaan multinasional dalam komoditi tertentu.

d) Forum perundingan GATT yang tersendat-sendat sehingga dapat menghambat ekspor.

e) Dan lain-lain.

\section{Memasuki Tinggal Landas.}

Berdasarkan uraian-uraian pada bab-bab terdahulu maka jelas bahwa melalui peletakan landasan kebijaksanaan pengembangan industri yang berwawasan jauh kedepan, yang menjangkau Repelita VI dan VII telah dilaksanakan yang tertuang dalam kebijaksanaan Strategis Utama berupa Pola Pengembangan Industri Nasional. Disadari bahwa masih terdapat beberapa kelemahan berdasarkan pengalaman-pengalaman yang diperoleh. Dalam kaitan ini maka apa yang telah berkembang baik pada Pelita $\mathrm{V}$ perlu lebih dimantapkan dan dikembangkan, sedangkan kelemahan-kelemahan yang ada berupaya untuk diperbaiki dan dibenahi, untuk selanjutnya dapat dimantapkan dan dikembangkan.

Memasuki tahap tinggal landas tersebut maka industrialisasi harus makin dipacu, agar peranan sektor industri sebagai penggerak utama pembangunan makin mantap, sehingga perannya sebagai pilar penopang pembangunan ekonomi menjadi semakin kokoh, sekaligus saling terkait dengan sektor pertanian yang telah berhasil menjadi pilar pertama dalam pembangunan ekonomi. Sektor industri yang makin dipacu 
pertumbuhannya memerlukan dukungandukungan yang kuat dari sektor lain seperti tersedianya sumber bahan baku utamanya yang terbaharui (pertanian, kehutanan), sumber daya manusia yang makin berkualitas, kemampuan penguasaan teknologi, dana investasi, penyediaan jasajasa seperti telekomunikasi, perdagangan, transportasi, rancangan bangun dan perekayasaan, pengembangan industri yang berwawasan lingkungan serta makin mampu mendukung usaha pemerataan dan penerapan tenaga kerja.

Di samping itu memasuki tahap tinggal landas juga diwamai kondisi-kondisi yang lebih berat seperti makin derasnya arug globalisasi, makin redanya pertentangan politik negara-negara adikuasa dan berakhimya perang dingin. Hal tersebut akan makin mendorong konsentrasi pada bidang ekonomi yang akan makin meningkatkan persaingan antar negara dengan konsekuensi bahwa peningkatkan daya saing industri kita harus makin kuat dan kokoh.

\section{Memasuki Era Globalisasi}

Sejak Pelita IV industri nasional sudah mengantisipasi tendensi perubahan masyarakat menuju globalisasi karena sejak Orde Baru bangsa Indonesia menganut ekonomi terbuka. Kemampuan ekspor hasil industri kian menunjukkan kesiapan industri memasuki era globalisasi. Dalam era globalisasi ekonomi itu telah diambil langkah-langkah strategis :

1) Mengembangkan industri dengan daya saing kuat.

2) Meningkatkan daya saing produk industri.

3) Secara ofensif melakukan ekspor.

Dalam memasuki era globalisasi tersebut pengembangan industri ditempuh dengan sikap dasar : wawasan jauh kedepan, memperhatikan lingkungan strategis, yang keduanya itu dipadukan untuk mengembangkan kekuatan industri nasional.

1) Kebijaksanaan pembangunan industri nasional yang tersusun dalam Pola Pengembangan Industri Nasional diletakkan dengan wawasan jauh kedepan. Dalam pelaksanaannya senantiasa memperhatikan lingkungan strategis yang berpengaruh baik pada tingkat nasional, regional maupun global.

2) Dengan cermat pengembangan industri nasional mengamati perubahan dunia yang terjadi (geopolitical landscape) dalam bentuk regionalisasi atau blok-blok ekonomi.

1. Eropa sedang berkembang menuju pasar tunggal Eropa yang dirintis oleh EC'12 yang akan berkembang dengan bergabungnya EFTA dan negaranegara Eropa Timur yang sedang bersiap memasuki sistem ekonomi terbuka.

2. Amerika Serikat mempelopori pendirian NAFTA dengan kecenderungan menjangkau seluruh benua Amerika.

3. Menghadapi regionalisasi ini, dalam pengembangan industri nasional telah mengambil sikap :

- Mensukseskan putaran Uruguay dari GATT agar supaya terjadi hubungan perdangan internasional yang lebih baik.

- Melaksanakan AFTA melalui mekanisme CEPT.

- Meningkatkan kerjasama SelatanSelatan utamanya dalam kerjasama ekonomi dan teknologi.

Disadari bahwa tendensi perubahan masyarakat dunia dimasa datang akan penuh dengan konflik ekonomi dalam rentangan arus globalisasi dengan regionalisasi, maka industri nasional sudah disiapkan dengan cermat untuk secara mantap mampu memasuki era globalisasi, maka industri nasional sudah disiapkan dengan cermat untuk 
secara mantap mampu memasuki era globalisasi. Globalisasi ekonomi penuh peluang dan harapan, namun tidak sedikit hambatan dan rintangan. Oleh karena itu dalam mengembangkan industri nasional sangat ditekankan peningkatan daya saing serta kerjasama yang erat dan saling menguntungkan antara Indonesia dengan negara-negara lain.

\section{Relokasi Industri}

Semenjak akhir Pelita IV terjadi perubahan cepat pada negara-negara maju, utamanya Jepang dan negara-negara industri maju. Banyak industri-industri mereka tidak kompetitif lagi yang disebabkan berbagai faktor antara lain dicabutnya GSP naiknya biaya tenaga, kelangkaan bahan baku dan lain-lain. Di lain pihak mereka ingin tetap mempertahankan kemampuan ekspor untuk masuk pasaran global. Kondisi ini mendorong negara-negara industri itu mengadakan relokasi industri kenegara-negara berkembang. Indonesia, Thailand, Malaysia, RRC, Mexico dan lain-lain merupakan daerah tujuan relokasi yang baik. Relokasi ini sudah barang tentu merupakan peluan bagi negaranegara berkembang yang sedang melakukan industrialisasi. Dan diketahui bahwa proses relokasi industri itu tidak akan berlangsung lama. Sehingga perlu diambil langkahlangkah untuk dapat memanfaatkan peluang itu seoptimal mungkin.

1) Relokasi industri dari negara maju mencakup semua industri yang sudah tidak kompetitif lagi di negara asalnya yang pada umumnya mempunyai pasasran global. Untuk pengembangan industri, Indonesia memerlukan relokasi industri tersebut.

2) Dalam memanfaatkan peluang relokasi itu Indonesia mengambil langkah-langkah :

(1) menciptakan iklim usaha yang semakin kondusif.
(2) membangun kawasan-kawasan industri termasuk kawasan terikat.

(3) penyediaan sarana dan prasarana

3) Dampak positif yang sudah mulai dirasakan dalam memanfaatkan relokasi industri itu antara lain kemajuan pesat industri tekstil dengan ekspornya yang terus meningkat, begitu pula industri sepatu, elektronika, mainan anak-anak, industri barang modal dan lain-lain.

\section{Peningkatan Pemerataan}

Pembangunan industri nasional diselenggarakan dengan berpedoman pada Trilogi Pembangunan. Pertumbuhan industri bergerak dengan cepat semenjak 8 tahun terakhir ini, senantiasa diiringi dengan upaya pemerataan dalam arti luas. Program pemerataan ditempuh baik secara sektoral maupun regional yang dilaksanakan secara terpadu guna mewujudkan industri nasional yang tangguh. Diharapkan pada waktu-waktu yang akan datang industri nasional berkembang secara serasi antara industri dasar, industri hilir dan industri kecil serta berkembang diseluruh Indonesia. Langkahlangkah yang diambil dalam melaksanakan program pemerataan itu adalah :

1. Pengembangan industri kecil.

Sudah menjadi tekad Pemerintah, pada tahun 1991 dan selanjutnya perkembangan industri kecil terus ditingkatkan dengan cara :

(1) Melaksanakan program Bapak Angkat sebanyak mungkin yang dilakukan oleh :

- Perusahaan swasta besar dan menengah yang sehat.

- Badan Usaha Milik Negara, tidak saja BUMN di lingkungan Departemen Perindustrian melainkan meluas pada seluruh BUMN yang ada. 
Pelaksanaan program Bapak Angkat ini diarahkan utamanya pada pemanfaatan $20 \%$ kredit perbankan KUK, pemanfaatan penyisihan 1 5\% laba BUMN dan lain-lain.

(2) Penjualan saham perusahaan kepada Koperasi.

Penjualan saham perusahaan industri ini diarahkan kepada Koperasi Karyawan, Koperasi Unit Desa (KUD) dan Koperasi lainnya terkait utamanya KOPINKRA. Penjualan saham kepada koperasi ini akan imempunyai dampak pemerataan juga dapat ditingkatkan daya saing dari perusahaan industri yang bersangkutan.

(3) Peningkatan bantuan pendidikan dan latihan untuk industri kecil.
Pelaksanaannn program keterkaitan dalam bentuk kerjasama saling menguntungkan antara Bapak Angkat Mitra Usaha industri kecil dan penjualan saham perusahaan kepada koperasi, diharapkan dapat menjadi Gerakan Nasional yang dilaksanakan di seluruh Indonesia sebagai salah satu sarana mewujudkan pemerataan serta tata ekonomi sesuai makna pasal 33 UUD 1945. Hingga bulan Maret 1992 telah dikukuhkan kerjasama 7.000 'Bapak Angkat dengan 37.000 Mitra Usaha Industri Kecil.

Perkembangan industri kecil dilaksanakan dengan prioritas pemecahan masalah pasar utamanya dilaksanakan melalui program keterkaitan sistem Bapak Angkat.

Perkembangan yang telah dicapai selama ini adalah sebagai berikut :

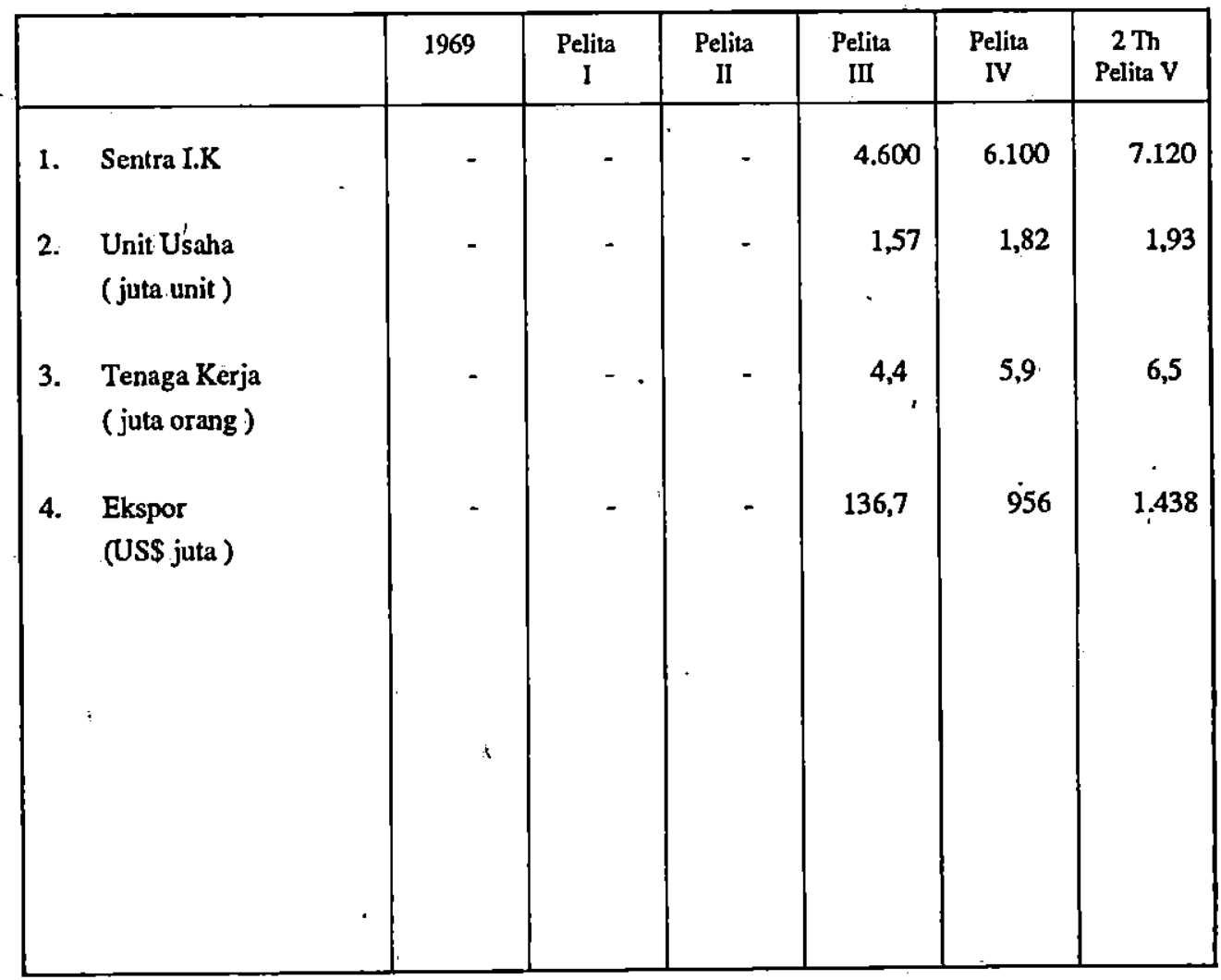


Yang menggembirakan adalah pembangunan industri kecil yang mampu meningkatkan pemerataan pembangunan di daerah-daerah di luar Jawa.

2) Pengembangan industri menengah dari kelompok aneka industri.

(1) Kelompok aneka industri berkembang sangat cepat; hingga sekarang tercatat 28.000 perusabaan.

(2) Kelompok industri menengah ini tersebar di hampir seluruh wilayah Indonesia, sesuai potensi masingmasing daerah.

Industri menengah dari kelompok aneka industri ini terus didorong perkembangannya guna semakin membuka peluang usaha dan penyediaan lapangan kerja.

3) Penyebaran Industri di daerah.

Pengembangan industri terus didorong pemerataannya keseluruh wilayah Indonesia sesuai potensi daerah, melalui pertumbuhan Wilayah Pusat Pertumbuhan Industri (WPPI) yang didalamnya terdapat Zona Industri, Kantong Industri di IBT, Kawasan Industri dan sentra industri kecil. Dengan tumbuh dan berkembangnya wilayahwilayah pengembangan ekonomi melalui WPPI, maka dapat ditingkatkan pembangunan sektor industri serta keterkaitannya dengan sektor ekonomi lainnya yang berkembang secara terpadu dalam suatu tata ruang tertentu. Dewasa ini terdapat 5 WPPI dengan 34 Zona, 3 WPPI sedang dikembangkan, terdapat 101 Kawasan Industri dan 6.092 Sentra Industri Kecil. Upaya penyebaran pembangunan industri ini telah dikembangkan sehingga potensi sumber daya alam yang terdapat ditanah Indonesia itu dapat dimanfaatkan bagi sebesar-besar keperluan masyarakat dan pada gilirannya integrasi dari WPPI serta sinergi semua sektor terkait dapat ikut mewujudkan wawasan Nusantara.

(1) Pengembangan sentra-sentra industri kecil yang tersebar diseluruh wilayah Indonesia. Pengembangan sentrasentra industri kecil ini dikaitkan dengan program Bapak Angkat.Bapak Angkat untuk IBT telah ditugaskan BUMN dan perusahaan swasta tertentu.

(2) Pengembangan industri kecil di IBT utamanya dalam bentuk pengembangan industri kecil dan industri yang berdaya saing kuat untuk memasuki pasaran ekspor. Industri daya saing kuat di IBT sudah mulai berkembang pada lokasilokasi tertentu yang berupa kantongkantong industri. Dengan pengembangan wilayah pembangunan industri yang merupakan upaya pemerataan pembangunan melalui pendekatanregional tersebut, pada akhirnya merupakan perwujudan Wawasan Nusantara.

\section{Pengembangan Usaha Kecil dan Menengah.}

Sejalan dengan perkembangan industri yang semakin meningkat, usaha kecil dan menengah juga terus berkembang. Usaha menengah dan kecil banyak bergerak pada kelompok aneka industri dan industri kecil. Dalam upaya meningkatkan peranan usaha menengah dan kecil telah diambil langkahlangkah :

1) Méningkatkan pengembangan industri kecil melalui pelaksanaan program keterkaitan dan memperluas pencadangan usaha untuk industri kecil.

(1) Pelaksanaan program keterkaitan digerakkan dengan sebanyak 
mungkin mengangkat Bapak Angkat bagi usaha kecil. Bapak Angkat ini tidak saja dilakukan oleh BUMN melainkan juga oleh perusahaan swasta, tidak saja oleh Departemen Perindustrian melainkan juga oleh semua instansi dan Pemerintah Daerah.

(2) Pencadangan usaha untuk industri kecil terus diperluas agar supaya semakin mendorong tumbuhnya wiraswasta baru yang bergerak di industri kecil dalam jumlah yang besar.

2) Mempersiapkan dan mendorong pelaksanaan modal ventura baik untuk usaha kecil maupun usaha menengah. Untuk itu perlu :

(1) Dukungan perbankan guna penyediaan modal.

(2) Kesediaan usaha besar dan menengah terjun dalam venture capital.

(3) Memperluas pendidikan dan latihan bagi persiapan tenaga-tenaga yang hendak berusaha dalam rangka modal ventura.

3) Meningkatkan pengembangan industri berskala menengah. Selain usaha menengah di sektor industri yang memang sudah berkembang cepat, seyogyanya dikembangkan pula usaha menengah di sektor-sektor lainnya seperti pertanian, perdangan, parpostel dan lainlain.

4) Mendorong berkembangnya industri tertier/jasa dalam arti luas, utamānya industri jasa keteknikan karena peluangnya cukup besar.

\section{Sumber Daya Manusia}

Dalam pembentukan masyarakat industri yang maju maka peranan SDM sebagai pelaku industri baik sebagai wiraswasta maupun tenaga profesi menjadi sangat strategis dan menentukan. Dalam menunjang proses industrialisasi yang bergerak semakin cepat dan dinamis, dituntut tersedianya tenaga profesi dan wiraswasta industri yang cukup baik dari segi kualitas maupun kuantitas.

Oleh karena itu SDM menempati posisi kunci dan mempunyai peranan yang sangat penting, maka dalam era tinggal landas nanti, pengembangan SDM menempati prioritas penting yaitu terciptanya kualitas manusia dan kualitas masyarakat Indonesia yang maju dalam suasana sejahtera lahir batin.

Untuk mengatasi kesenjangan "tersebut telah, sedang dan akan diupayakan secara terus-menerus hal-hal sebagai berikut :

(1) Pengembangan tenaga profesi melalui 3 jalur yaitu : pendidikan formal, pendidikan dan latihán kerja, pengalaman kerja melalui sistem magang dan latihan di tempat.

(2) Pengisian tenaga profesi dan penggantian tenaga kerja (ahli) asing pada perusahaanperusahaan industri.

(3) Pengembangan wiraswasta-wiraswasta industri melalui berbagai diklat usaha mandiri disektor industri.

Di bidang penyediaan tenaga profesi industri telah diarahkan tersedianya tenaga profesi yang ahli, terampil, terlatih dan mempunyai sikap profesionalisme yang tinggi terutama untuk tenaga teknisi menengah ke atas.

$\mathrm{Di}$ bidang pengembangan tenaga wiraswasta-wiraswasta diarahkan untuk mewujudkan wiraswasta yang tangguh mampu beradaptasi dengan segala perubahan terutama wiraswasta tingkat menengah dan kecil.

Penguasaan Teknologi Industri.

Kemampuan bangsa dalam penguasaan teknologi industri berkembang semakin maju 
sehingga dapat membentuk basis yang kuat bagi pengembangan kemampuan teknologi berspektrum luas (broad based technology) yang tercermin dengan dikuasainya teknologi diberbagai kelompok industri, industri dasar, aneka industri dan industri kecil. Kemampuan penguasaan teknologi itu mencakup kemampuan dalam rancangan bangun perekayasaan dan litbang madya maupun teknologi maju/canggih.

Sejalan dengan perkembangan industri, kemampuan penguasaan teknologi makin luas basisnya, tampak pada :

(1) Penguasaan Teknologi Produksi

Telah membentuk basis yang kuat bagi pengembangan kemampuan teknologi berspektrum luas, yang tercermin dari :

- Industri kecil sebanyak 2 juta unit usaha menerapkan teknologi sederhana.

- Industrí skala menengah sebanyak 28.000 pabrik menerapkann teknologi madya dan sebagian teknologi canggih.

- Industri dasar (IKD dan IMLDF) berjumlah 2.000 unit, menerapkan teknologi canggih.

(2) Penguasaan Rancangan Bangunan dan Perekayasaan Industri

- Kemampuan rancangan bangunan dan perekayasaan industri semakin mantap dalam pembuatan mesin peralatan pabrik dan peralatan lainnya maupun bangunan pabrik. Untuk pembangunan pabrik pupuk, semen, kertas dan besi baja kekuatan intinya terdapat pada industri pengolahan berstatus PMDN.

- Di samping mampu menangani pembangunan pabrik sendiri, usaha nasional secara bertahap mulai memasuki pasaran ekspor, misalnya pembangunan pabrik pupuk di Malaysia, pabrik tekstil di Inggris, pabrik Aluminium Fluorida di RRC dan lain-lain.

\section{Industri yang Berwawasan Lingkungan}

Dengan mengacu pada UU No. 5 Tahun 1984 tentang Perindustrian, UU No. 4 Tahun 1982 tentang Pokok-pokok Pengelolaan Lingkungan Hidup serta PP No. 29 Tahun 1986 tentang AMDAL, maka Departemen Perindustrian bekerjasama dengan Kantor Menteri Negara Kependudukan dan Lingkungan Hidup meningkatkan pelaksanaan pengamanan yang ketat atas seluruh kegiatan industri agar supaya perkembangan industri benar-benar dapat :

a) Mengamankan aspek-aspek fungsi lingkungan hidup, utamanya dalam menjaga kelestarian sumber daya alam bagi industri menuju terciptanya pembangunan yang berkelanjutan.

b) Saling mendukung dan menguatkan dengan pembangunan sektor-sektor lainnya dalam memanfaatkan sumber daya alam yang terbatas, sehingga semua sumber daya itu dapat dimanfaatkan secara optimal bagi pembangunan nasional.

c) Menciptakan lingkungan yang sejauh mungkin bebas pencemaran baik pencemaran air, udara, debu, suara maupun bentuk-bentuk pencemaran lainnya, sehingga industri dapat hidup dan berkembang secara serasi dengan alam serta masyarakat sekitarnya.

Dalam upaya mewujudkan industri yang berwawasan lingkungan tersebut, maka telah diadakan kegiatan terpadu antara Departemen Perindustrian dengan Kantor Menteri Negara KLH dalam :

(1) Penyusunan peraturan dan kebijaksanaan di bidang lingkungan hidup yang mempengaruhi /melibatkan kepentingan pengembangan industri (termasuk penetapan standar-standar nasional di bidang pencemaran) 
(2) Evaluasi AMDAL kegiatan industri melalui Komisi AMDAL.

(3) Pernantauan dan pengawasan kegiatan industri yang mempunyai potensi ancaman dampak lingkungan negatif.

(4) Pemecahan masalah/kasus, pencemaran dan kerusakan lingkungan hidup yang skàlanya memerlukan pemecahan bersama.

(5) Kampanye dan pemasyarakatan budaya lingkungan hidup.

(6) Kajian-kajian masalah pencemaran dan lingkungan hidup.

(7) Studi-studi pembangunan unit-unit pengolahan limbah B3 yang terpusat dan konsepsi operasionlisasinya.

(8) Peningkatan kemampuan aparatur pemerintah baik kelembagaan, sarana maupun personalia.

Upaya untuk mengembangkan industri yang berwawasan lingkuangan ini terus ditingkatkan baik secara preventif maupun represif sesuai ketentuan yang telah tercantum dalam UU No. 5 Tahun 1984 tentang Perindustrian.

\section{Industri Jasa Tersier}

Perkembangan industri nasional sudah mulai mampu merubah struktur ekonomi yang seimbang antara industri dan pertanian. Intensitas perubahan struktur tersebut memberikan dampak luas pada kegiatan ekonomi lainnya, utamanya dalam menumbuhkembangkan kegitan jasa, kegiatan jasa yang lus, merupakan lapangan berusaha bagi masyarakat luas. Apabila kita amati perkembangan proses industrialisasi di negra-negara maju, maka dapat diamati proses perkembangan yang fundamental sebagai berikut :

- Apabila pernanan sektor industri pada
PDB telah melewaiti $15 \%$, maka perkembangan industri akan cepat, asalkan iklim yang menunjang kondusif. Perkembangan ini sesuai dengan apa yang dialami oleh Indoesia tahun-tahun terakhir ini.

- Apabila peranan sektor industri pada PDB mencapai sekitaar 19-20\%, maka akan mendorong pertumbuhan industri jasa (tersier), dimana peluang tersebut memerlukan penanganan oleh tenaga akademis dan perguruan tinggii. Peranan sektor industri Indonesia pada PDB tahun 1991 mencapai $22,22 \%$, karena itu diperkirakan industri jasa (tertier) akan tumbuh dengan cepat. Peluang tersebut perlu dimanfaatkan oleh tenaga profesi yang pada umumnya berpendidikan tinggi dan dunia perguruan tinggi.

Industri jasa (tersier) yang berkembang itu antara lain adalah :

1) Jasa keteknikan/perekayasaan.

Telah berkembang industri jasa di bidang keteknikan, utamanya dalam

(1) Jasa engineering dalam rancang bangun dan perekayasaan, unțk peralatan pabrik, peralatan canggih. lainnya serta pabrik secara utuh.

(2) Jasa pemeliharaan/repair and maintenance mesin-mesin dan peralatan pabrik lainnya, termasuk inspeksi teknis.

(3) Jasa pengembangan teknologi melalui berbagai kegiatan litbang terapan guna mendukung daya saing produksi.

(4) Jasa konstruksi pabrik secara utuh.

(5) Jasa inspeksi peralatan canggih.

(6) Jasa survey, pengujian mutu dan lainlain.

(7) Jasa penyiapan AMDAL

(8) Jasa-jasa keteknikan lainnya. 
2) Jasa-jasa lain seperti jasa manajemen, keungan, perbankan, jasa promosi, jasa indormasi dan lain-lain.

\section{Penutup.}

Melalui peletakan kebijaksanaan strategis utama kebijaksanaan penunjang yang dilancarkan semenjak awal Pelita IV yang sekalaigus juga merupakan strategi Pembangunan Industri Nasional Indonesia, maka pada akhir PJPT I atau akhir Pelita V sektor industri telah mampu memenuhi amanat GBHN yaitu terciptanya keseimbangan antara sektor industri dengan sektor pertanian. Hal tersebut tercermin antara lain dari sumbangan sektor industri pada akhir tahun 1991 telah mencapai $22,22 \%$ dan sektor pertanian $19,62 \%$. Disamping itu sektor industri telah mampu berperan sebagai penggerak utama, pembangunan, utamanya mampu meningkatkan ekspor non migas dimana pada tahun 1991 ekspor nonmigas. mencapai US\$ 10.247,0 milyar dibanding dengan ekspor migas US\$10.804,9 milyar. Ekspor hasil indusrti (industri pengolahan) mencapai US $\$ 15.386,0$ milyar atau $84,32 \%$ dari total ekspor non migas atau $52,80 \%$ dari total seluruh ekspor.

Keberhasilan sektor industri seperti tersebut diatas juga didukung oleh makin meningkatnya daya saing komoditi hasil industri sehingga mampu melakukan terobosan dan penetrasi ke pasaran internasional. Peningkatan daya saing tersebut diupayakan melalui :

- Pengembangan industri yang memanfaatkan sumber daya alam

- Pengembangan industri yang memanfaatkan keunggulan sumber daya manusia.

- Pengembangan industri yang merupakan gabungan antara keduanya.
Dalam usaha mengembangkan sektor industri disamping diarahkan untuk mempercepat laju pertumbuhan ekonomi, secara simultan juga dikembangkan upaya menuju pemerataan ekonomi melalui pengembangan industri kecil yang dilakukan melalui sentra industri kecil maupun industri kecil non sentra. Program pembinaan telah dilakukan dan akan selalu ditingkatkan melalui program Bapak Angkat- Anak Angkat serta Kopinkra-kopinkra di daerahdaerah. Disamping itu juga penyediaan dana melalui BUMN yang menyisihkan 5\% dari keuntungan bersih untuk pembinaan industri kecil dan berbagai fasilitas seperti Unit Pelayanan Teknis di seṇtra-sentra industri kecil. Bantuan penyediaan dana perbankan $20 \%$ untuk pengusaha golongan ekonomi lemah termasuk industri kecil serta penyerahan pemilikan saham dari industri besar kepada koperasi.

Persebaran industri dilakukan melalui pengembangan Wilayah Pusat Pertumbuhan Industri (WPPI). Zona-zona industri, Kawasan-kawasn Industri dan kantongkantong Industri. Pembentukan WPPI diharapkan akan secara simultan mengembangkan wwlayah tersebut termasuk pengembangan industri kecil yang terkait dengan industri menengah dan besar.

Sejalan dengan perkembangan sektor industri berkembang pula kemampuan penguasaan teknologi termasuk rancang bangun dan perekayasaan industri, makin meningkatnya kualitas sumber daya manusia termasuk ketrampilan, kewiraswastaan, profesionalisme ddaamn managerial. Di samping itu tumbuhnya sektor industri juga dapat memacu pertumbuhan industri tertier yang berupa industri jasa-jasa seperti jasa perbankan, jasa keteknikan, perdagangan, telekomunikasi dan sebagainya.

Menyongsong memasuki tahap tinggal landas sektor industri harus makin dipacu perkembangannya. Dalam kaitan tersebut 
maka pemantauan terhadap lingkungan strategis yang berpengaruh perlu makin ditingkatkan mengingat makin dérasnya arus globalisasi dan terkonsentrasi kegiatan negara -negara pada bidang ekonomi sebagai akibat berakhirnya perang dingin. Untuk itu peningakatan daya saing harụs makin ditingkatkan melalui pengingkatan efisiensi dan produktivitas sektor industri.
Dalam mempercepat laju industrialisasi dan industri yang berdaya saing kuat, maka dukungan sektor lain sangat diperlukan seperti antara lain : dana investasi, sumbar daya manusia yang makin berkualitas, pengusaan teknologi, perdagangan, telekomunikasi, transportasi dan sebagainya. Diharapkan pada PJPT II maka peranan industri jasa-jasa akan sangat meningkat. 